\title{
Generation of $\mathbf{V} \mathbf{a} 13 / \beta 21^{+} \mathrm{T}$ cell specific target $\mathrm{CML}$ cells by TCR gene transfer
}

\author{
Xianfeng Zha ${ }^{1,2,3}$, Ling $\mathrm{Xu}^{2}$, Shaohua Chen ${ }^{2}$, Lijian Yang ${ }^{2}$, Yikai Zhang ${ }^{2}$, Yuhong Lu ${ }^{4}$, \\ Zhi Yu ${ }^{4}$, Bo Li ${ }^{2}$, Xiuli Wu' ${ }^{2}$, Wenjie Zheng ${ }^{3}$, Yangqiu Li ${ }^{2,4,5}$ \\ ${ }^{1}$ Department of Clinical Laboratory, First Affiliated Hospital, Jinan University, Guangzhou, China \\ ${ }^{2}$ Institute of Hematology, Jinan University, Guangzhou, China \\ ${ }^{3}$ Department of Chemistry, Jinan University, Guangzhou, China \\ ${ }^{4}$ Department of Hematology, First Affiliated Hospital, Jinan University, Guangzhou, China \\ ${ }^{5}$ Key Laboratory for Regenerative Medicine of Ministry of Education, Jinan University, Guangzhou, China \\ Correspondence to: Yangqiu Li, email: yangqiuli@hotmail.com \\ Keywords: chronic myeloid leukemia, $T$ cell receptor, gene transfer, immunotherapy
}

Received: May 02, $2016 \quad$ Accepted: September 13, 2016

Published: October 04, 2016

\section{ABSTRACT}

Adoptive immunotherapy with antigen-specific $\mathbf{T}$ cells can be effective for treating melanoma and chronic myeloid leukemia (CML). However, to obtain sufficient antigen-specific $T$ cells for treatment, the $T$ cells have to be cultured for several weeks in vitro, but in vitro $\mathrm{T}$ cell expansion is difficult to control. Alternatively, the transfer of $T$ cell receptors (TCRs) with defined antigen specificity into recipient $T$ cells may be a simple solution for generating antigen-specific $T$ cells. The objective of this study was to identify CML-associated, antigen-specific TCR genes and generate CML-associated, antigen-specific $T$ cells with $T$ cell receptor (TCR) gene transfer. Our previous study has screened an oligoclonal V 321 with a different oligoclonal Va partner in peripheral blood mononuclear cells (PBMCs) derived from patients with CML. In this study, oligoclonally expanded TCR a genes, which pair with TCR V 321 , were cloned into the pIRES eukaryotic expression vector (TCR Va-IRES-V $\beta 21$ ). Next, two recombinant plasmids, TCR Va13-IRES-V $\beta 21$ and TCR Va18-IRES-V $\beta 21$, were successfully transferred into $T$ cells, and the TCR gene-modified $T$ cells acquired CML-specific cytotoxicity with the best cytotoxic effects for HLA-A11+ K562 cells observed for the TCR Va13/Vß21 gene redirected T cells. In summary, our data confirmed TCRVa13/V 321 as a CML-associated, antigen-specific TCR. This study provided new evidence that genetically engineered antigen-specific TCR may become a druggable approach for gene therapy of CML.

\section{INTRODUCTION}

Chronic myelogenous leukemia (CML) is a common hematological malignancy in adult. The typical genetic alteration is the Philadelphia chromosome resulting from,t( $(9 ; 22)$ (q34;q11), which forms a bcr-abl fusion gene encoding BCR-ABL fusion proteins with unusual tyrosine kinase activity [1]. Therefore, tyrosine kinase inhibitors (TKIs) such as imatinib were developed as ATP competitive inhibitors of the bcr-abl tyrosine kinase fusion protein for CML therapy [2]. Compared with previous standard therapy, treatment with imatinib have improved significantly the outcome of the patients with CML. However, approximately $30 \%$ of patients interrupt imatinib therapy because of suboptimal response or intolerance, in the case, the second-generation TKIs are the choice for the patients [3,4]. It is well known, allogenic hematopoietic stem cell transplantation (alloHSCT) is currently the only curative therapeutic approach for CML. However, the application of such procedure is suitable only for approximately $30 \%$ of CML patients due to the limitation of the availability of matched donors and the toxicity in older patients $[5,6]$. Adoptive $\mathrm{T}$ cell immunotherapy is an effective alternative for treating CML patients, particularly patients with relapsed CML after HSCT. Donor lymphocyte infusion (DLI) has improved the outcome of relapsed CML patients after allo-HSCT, which has replaced IFN- $\alpha$ as the preferred treatment for 
relapsed CML after HSCT [7, 8]. Infused donor-derived cytotoxic $\mathrm{T}$ lymphocytes (CTLs) recognize leukemia associated antigens expressed by CML cells, resulting in CTL-mediated leukemia cell death. Unfortunately, a part of CTL-recognized also allo-antigens which are expressed in host normal tissues, which can lead to graft-versus-host disease (GVHD). Hence, the ideal strategy for adoptive $\mathrm{T}$ cell immunotherapy is to infuse leukemic antigenspecific cytotoxic T lymphocytes (CTLs). However, application of this mode of leukemic antigen-specific $\mathrm{T}$ cell adoptive transfer is often limiting because the isolation and in vitro expansion of leukemic antigen-specific $T$ cells is labor-intensive and time-consuming [9]. Fortunately, a recently developed $\mathrm{T}$ cell receptor (TCR)-mediated gene therapy may facilitate overcoming this limitation.

TCRs include $\alpha, \beta, \gamma$ and $\delta$ chains, most circulating mature T cells use the $\alpha / \beta$ heterodimeric TCR for specific recognition of antigenic peptides presenting by major histocompatibility complex (MHC) molecules from antigen presenting cells. The specific TCRs could be identified by characterizing the rearrangement of TCR $\alpha$ and TCR $\beta$ genes. Transfer of antigen-specific TCR genes into recipient $\mathrm{T}$ cells using transgenic method will lead to the transfer of leukemic-specific $\mathrm{T}$ cell immunity. Therefore, specific TCR gene transfer is an attractive strategy for the fast in vitro generation of sufficient numbers of antigen-specific $T$ cells [9]. To date, the successful transfer of TCR genes specific for virus-specific and tumor-associated antigens, such as EBV and MART-1 and Wilms' tumor antigen 1 (WT1), has been shown to have specific cytotoxicity for EBV+ lymphoma, leukemia and melanoma [10-13]. However, little is known about the TCR genes specific for CML-associated antigens.

Previously, we identified specific TCR gene sequences related with a CML-associated antigen, which was submitted to GenBank (the accession number: GU997647). In this study, we developed recombinant constructs containing HLA-A11-restricted TCR $\alpha 13$ and TCR $\beta 21$ genes specific for CML-associated antigens, and showed that the TCR gene-modified T cells had the specific cytotoxicity toward the HLA-A11+ K562 cell line. The results may indicate that it is viable to prepare leukemic antigen specific $\mathrm{T}$ cells from polyclonally expanded T cells when the MHC -restricted TCR genes are identified.

\section{RESULTS}

\section{Cloning of TCRs from CML patient and construction of TCR bicistronic eukaryotic expression plasmid}

In our previous study, oligoclonally expanded TCR $\alpha 13, \alpha 18$ and $\beta 21$ subfamily $T$ cells were identified in the PB of patients with CML [14]. In this study, full length TCR $\alpha 13, \alpha 18$ and $\beta 21$-chain genes were amplified by
PCR, and the TCR $\alpha 13$ and $\alpha 18$ genes, which pair with TCR $\beta 21$, were then cloned into the pIRES eukaryotic expression vector to construct two bicistronic recombinant plasmids, TCR $\alpha 13$-IRES- $\beta 21$ and TCR $\alpha 18$-IRES- $\beta 21$ (Figure 1). Subsequently, their sequence were verified by restriction enzyme digestion and sequencing (data not shown). To confirm expression of the TCR $\alpha 13$ and TCR $\beta 21$ chains, the TCR-encoding expression plasmids were first transfected into HEK 293 cells using lipofection technology. After transfection, the TCR $\alpha 13 / \beta 21$ and $\alpha 18 / \beta 21$ proteins could be detected by Western blotting (Figure 2A). Additionally, the TCR $\beta 21$ protein could be determined on Jurkat $\mathrm{T}$ cells labeled with a mouse antihuman TCR $\beta 21$-FITC monoclonal antibody by FCM $(70.2 \%$ and $72.2 \%$ ) (Figure 2B). These results indicate that the recombinant plasmid could be successfully expressed in eukaryotic cells.

\section{TCR $\alpha / \beta$ gene-modified $\mathrm{CD}^{+} \mathrm{T}$ cells}

$\mathrm{CD}^{+} \mathrm{T}$ cells were transfected with the TCR $\alpha 13$ IRES- $\beta 21$ and TCR $\alpha 18$-IRES- $\beta 21$ recombinant plasmids using Nucleofector ${ }^{\mathrm{TM}}$ technology. Twenty-four hours after transfection, the efficiencies of gene transfer were determined by FCM which detected the TCR $\beta 21$ on the $\mathrm{CD}^{+} \mathrm{T}$ cells (Figure 3 ). The TCR transfer efficiency of the TCR $\alpha 13$-IRES- $\beta 21$ and TCR $\alpha 18$-IRES- $\beta 21$ recombinant plasmids was $43.4 \pm 10.3 \%$ and $39.6 \pm 5.0 \%$, respectively. These data indicated that the two recombinant plasmids could express the inserted proteins in normal $\mathrm{T}$ cells, and the expression efficiency could satisfy subsequent toxicity tests.

\section{Specificity and functionality of TCR-transduced T cells}

We used multiple approaches to ensure that the TCR gene-modified $\mathrm{CD} 3^{+} \mathrm{T}$ cells were specific and active against antigen-expressing targets.

To test the TCR gene specificity, target cells must express corresponding MHC class-I molecules. K562 cells do not express MHC class-I molecules [15]; thus, to overcome this limitation, K562 cells were modified to express HLA-A* 11 molecules [16]. In addition, negative control HEK293 cells were also modified to express HLA-A*11 molecules.

Having verified that the exogenous TCRs were expressed equally in T cells and the HLA-A* $11^{+} \mathrm{K} 562$ target cell line, we evaluated the ability of the TCRmodified T cells to lyse their target cells using the calceinAM release assay. The killing efficiency was tested following the co-cultivation of effector cells (TCR $\alpha 13$ IRES- $\beta 21$, TCR $\alpha 18$-IRES- $\beta 21$ or pIRES-transduced T cells) with target cells (pEGFP-N3 ${ }^{+}$K562, HLA-A*11 ${ }^{+}$ $\mathrm{K} 562$, and HLA-A* $11^{+} \mathrm{K} 293$ cells). The specific killing efficiency of TCR $\alpha 13 / \beta 21$-transduced T cells toward 
HLA-A* $11^{+}$K562 cells was significantly higher than that for pEGFP-N3 ${ }^{+} \mathrm{K} 562(p=0.002)$ and HLA-A* $11^{+}$ K293 $(p=0.001)$ cells. The specific killing efficiency of TCR $\alpha 18 / \beta 21$-transduced T cells for the three target cells demonstrated differences, but these were not statistically significant. The specific killing efficiency of TCR $\alpha 13 /$ $\beta 21$-transduced T cells toward HLA-A* $11^{+}$K562 cells was significantly higher than that of TCR $\alpha 18 / \beta 21$-transduced $(p=0.005)$ and pIRES-transduced $(p=0.003)$ T cells. In co-cultivation experiments, we found that TCR $\alpha 13 / \beta 21$ transduced $\mathrm{T}$ cells had the highest killing efficiency for the HLA-A $* 11^{+} \mathrm{K} 562$ cell line (Figure 4), indicating that the TCR $\alpha 13 / \beta 21$-modified T cells were specifically directed against CML cells.

\section{Expression of granzyme B and perforin in TCR- transduced $T$ cells}

Granzyme B and perforin are expressed by CTLs and play an important role in their cytotoxic activity. Perforin is required for cytolysis, and granzymes efficiently induce target cell death; thus, the granzyme $\mathrm{B}$ and perforin expression level in TCR-transduced T cells can reflect cytotoxicity strength. We found that the granzyme B and perforin expression level in TCR $\alpha 13$ / $\beta 21$-transduced $\mathrm{T}$ cells in response to HLA-A* $11^{+} \mathrm{K} 562$ cells was 4.8- and 3.6-fold greater, respectively, than that in TCR $\alpha 18 / \beta 21$-transduced T cells, and the levels were 31.6- and 13.5-fold greater than that in empty plasmid transfected $\mathrm{T}$ cells. In addition, the expression level of granzyme B and perforin in TCR $\alpha 13 / \beta 21$-transduced
$\mathrm{T}$ cells in response to $\mathrm{HLA}-\mathrm{A} 11^{+} \mathrm{K} 293$ and $\mathrm{pEGFP}-$ $\mathrm{N} 3{ }^{+} \mathrm{K} 562$ cells was also greater than that in TCR $\alpha 18 / \beta 21$ transduced $\mathrm{T}$ cells and empty plasmid-transfected $\mathrm{T}$ cells (Figure 5).

\section{IFN- $\gamma$ secretion in TCR-transduced $\mathrm{T}$ cells}

IFN- $\gamma$ secretion is a symbol of $\mathrm{T}$ cell activation. Thus, TCR-transduced $\mathrm{T}$ cells were tested for IFN- $\gamma$ release in response to each target cell using specific ELIspot assays. We found that the IFN- $\gamma$ production of TCR $\alpha 13 / \beta 21$-transduced T cells $\left(168 \pm 5.8 \mathrm{SFC} / 2 \times 10^{4}\right.$ cells) in response to HLA-A* $11^{+} \mathrm{K} 562$ cells was greater than that of empty plasmid-transfected T cells $(58 \pm 1.8$ $\mathrm{SFC} / 2 \times 10^{4}$ cells $)(p<0.05)$, and it was also greater than its IFN- $\gamma$ production in response to the $\mathrm{pEGFP}-\mathrm{N} 3{ }^{+} \mathrm{K} 562$ $\mathrm{K} 562\left(64 \pm 1.09 \mathrm{SFC} / 2 \times 10^{4}\right.$ cells $)$ and HLA-A* $11^{+} \mathrm{K} 293$ $\left(42 \pm 7.5 \mathrm{SFC} / 2 \times 10^{4}\right.$ cells $)$ cell lines. A similar result was observed for TCR $\alpha 18 / \beta 21$-transduced T cells. However, the IFN- $\gamma$ production of TCR $\alpha 13 / \beta 21$-transduced T cells in response to the HLA-A* $11^{+} \mathrm{K} 562$ line was greater than that for TCR $\alpha 18 / \beta 21$-transduced T cells (Figure 6 ). These results suggest that both TCR $\alpha 13 / \beta 21$ - and $\alpha 18 / \beta 21$ transduced T cells specifically respond to CML cells, and TCR $\alpha 13 / \beta 21$-transduced T cells have the best response.

\section{DISCUSSION}

Increasing studies have demonstrated that adoptive transfer of TCR transgenic $\mathrm{T}$ cells is a promising strategy for treating patients suffering from malignancies

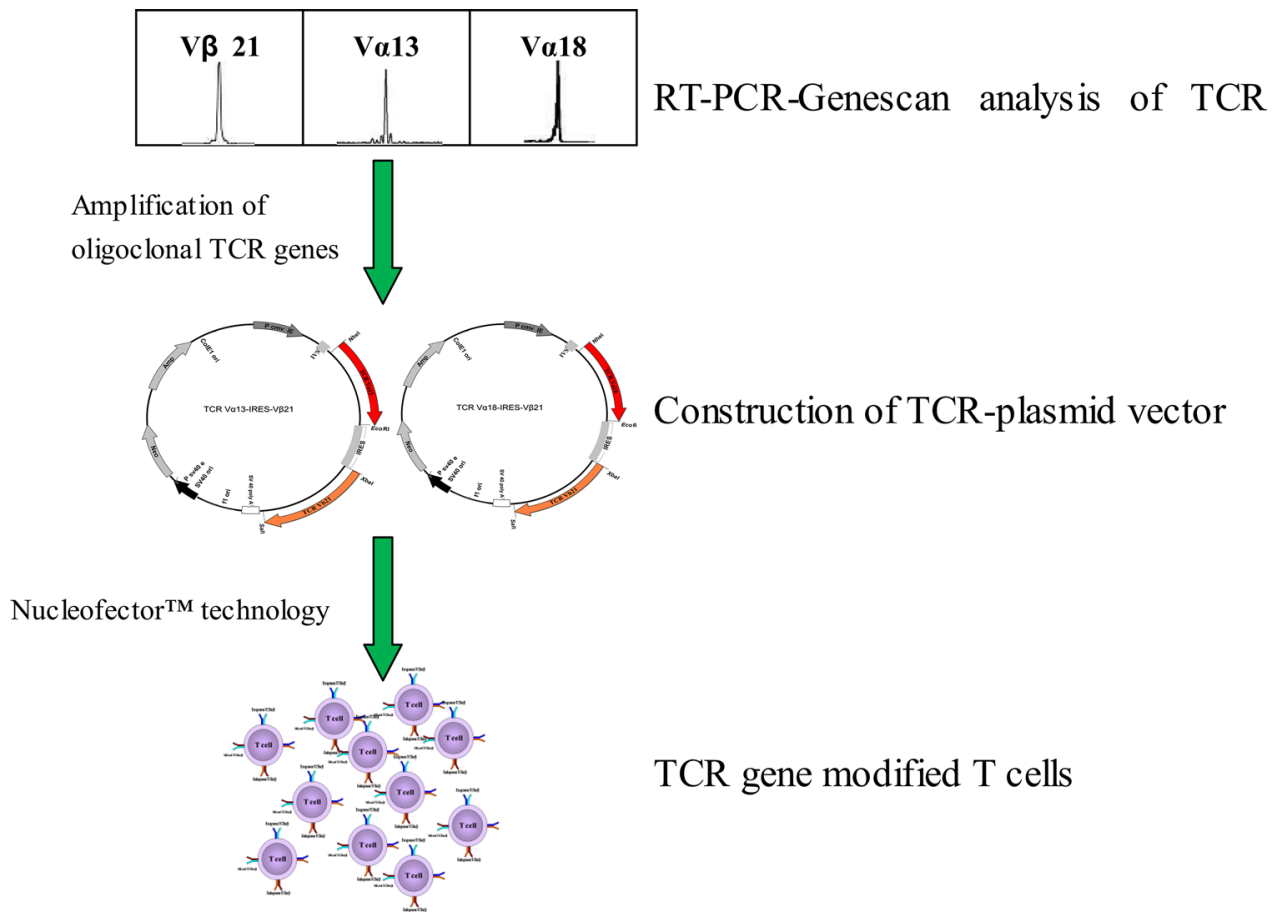

Figure 1: The schematic diagram of generation of CML associated antigen-specific T cells by TCR gene transfer. 
[17-19]. For clinical application of transgenic TCR $\mathrm{T}$ cells, obtaining tumor-associated, antigen-specific TCR from tumor-specific CTLs is a prerequisite. In CML, the p210 protein encoded by the BCL-ABL fusion gene has a unique advantage for obtaining antigen-specific TCR genes $[20,21]$. Several studies have also demonstrated that $\mathrm{p} 210$ protein fusion region-derived peptides bind to different MHC class-I molecules (A11 ,A0201 ,A3 and B8) and induce CML-specific cytotoxic $\mathrm{T}$ lymphocytes (CTL), which can kill CML cells in vitro [20, 22-26]. In addition, in vivo, bcr-abl fusion protein-specific CTLs were detected in PBMCs from CML patients using bcr-abl peptide/MHC tetramer technology [23]. Moreover, some leukemic-associated antigens such as WT1 and proteinase 3 (PR3), could also induce to yield CML-specific CTLs [15]. These CML-specific CTLs may consist of the same or different $\alpha \beta^{+} \mathrm{T}$ cell clones. The specific method for identifying antigen-specific TCRs from CML-specific CTLs is peptide/MHC tetramer technology; however, few specific TCRs have been identified from CML using peptide/MHC tetramer technology. Oligoclonally expanded $\mathrm{T}$ cells may dominate an immune response induced by malignant cells, thus exhibiting a limited set of TCR $\alpha$ or $\beta$ chains. Therefore, analysis of TCR usage in patients with leukemia is an excellent method for evaluating leukemic-specific immune responses [27]. RTPCR-Genescan is one of the sensitive methods used to analyze TCR usage and detect oligoclonal T cell expansion [28], and it is widely used to detect antigen-specific TCR $\mathrm{V} \beta$ and $\mathrm{V} \alpha$ genes in infectious diseases, tumors, and autoimmune diseases [29, 30]. We previously observed the oligoclonal TCR V $\beta 21$ gene at a high frequency (26.4\%) in CML using RT-PCR-Genescan technology, and in vitro oligoclonal V $\beta 21 \mathrm{~T}$ cells from cord blood could be induced by K562 cells, CML cells, as well as a BCR-ABL fusion peptide. Furthermore, the emergence of oligoclonal V $\beta 21 \mathrm{~T}$ cells was investigated in relapse CML patients post allo-HSCT after DLI, and clonality was retained until complete remission $[14,31,32]$. This evidence suggests that clonally expanded V $\beta 21 \mathrm{~T}$ cells may have an antiCML function.

Because TCR $\beta$ is just one chain in the TCR $\alpha / \beta$ complex, TCR $\beta$ clonal proliferation will theoretically accompany TCR $\alpha$ clonal proliferation. Thus in this study, the oligoclonally expanded TCR $\alpha 13$ and $\alpha 18$ genes were isolated from patients with CML using RT-PCR-Genescan technology, and these genes, which pair with V $\beta 21$, were cloned into the pIRES eukaryotic expression plasmid

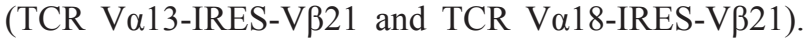
The two recombinant plasmids were transfected into $\mathrm{CD}^{+} \mathrm{T}$ cells from HLA-A $11^{+}$healthy donors to determine their specific cytotoxicity in vivo cytotoxicity assays. Using the TCR gene cloned from a CML patient carrying HLA-A11, we artificially established an HLA-A11 ${ }^{+} \mathrm{K} 562$

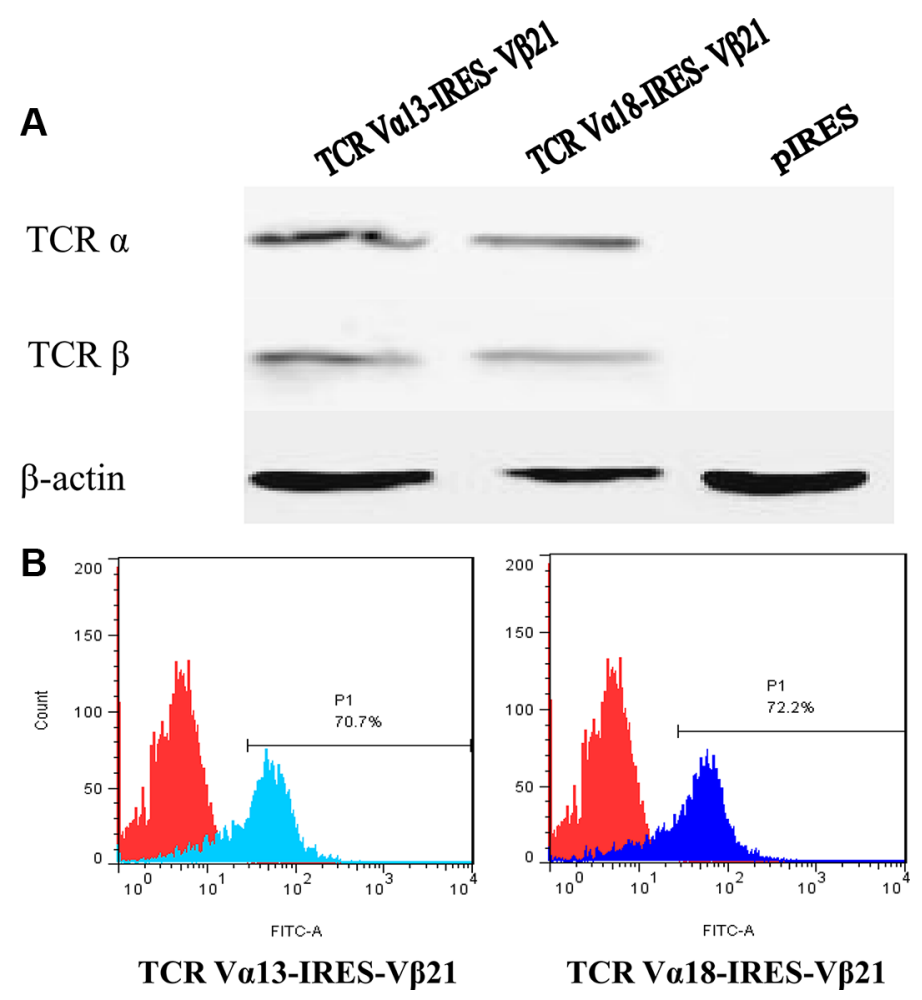

Figure 2: Expression of TCR $\alpha 13 / \beta 21$ and $\alpha 18 / \beta 21$ on HEK 293 cells and Jurkat T cells transduced with TCR V $\alpha 13-$

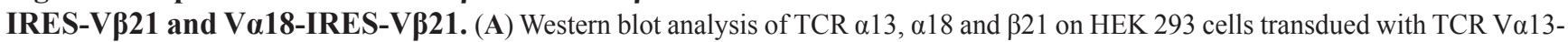
IRES- V $\beta 21$, V $\alpha 18$-IRES-V $\beta 21$ and pIRES. (B) Transduced Jurkat T cells were stained with mouse anti-human TCR V $\beta 21.3$ monoclonal antibody and analyzed by flow cytometry. 

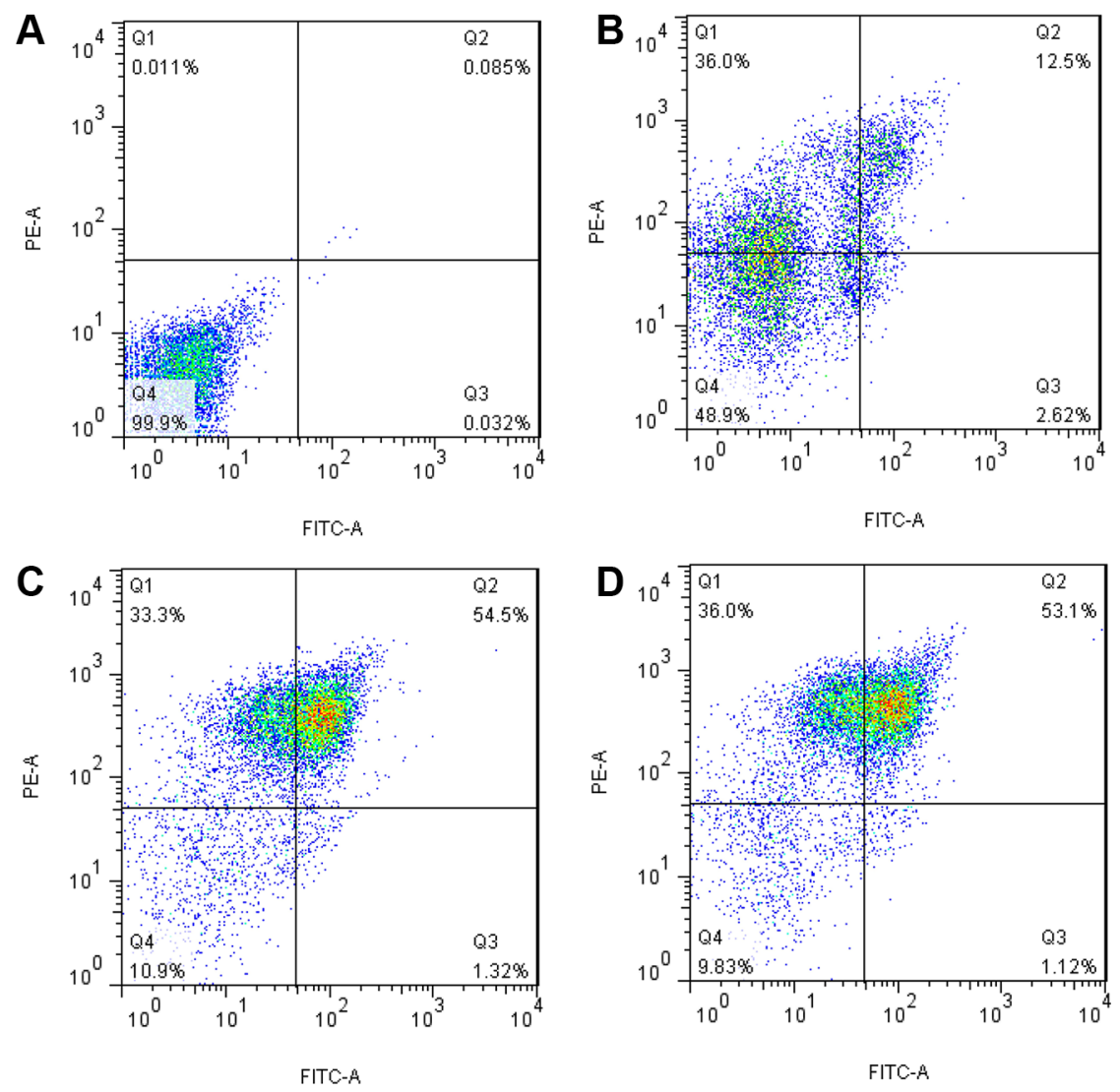

Figure 3: Expression of TCR $\alpha 13 / \beta 21$ and $\alpha 18 / \beta 21$ on $\mathrm{CD3}^{+} \mathrm{T}$ cells transduced with pIRES, TCR V $\alpha 13-I R E S-V \beta 21$ and TCR V $\alpha 18-I R E S-V \beta 21$. Transduced cells was were stained with mouse anti-human TCR V $\beta 21.3$ monoclonal antibody and analyzed by

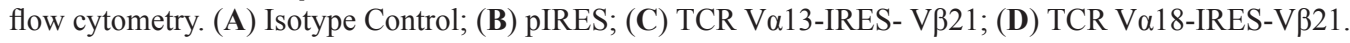

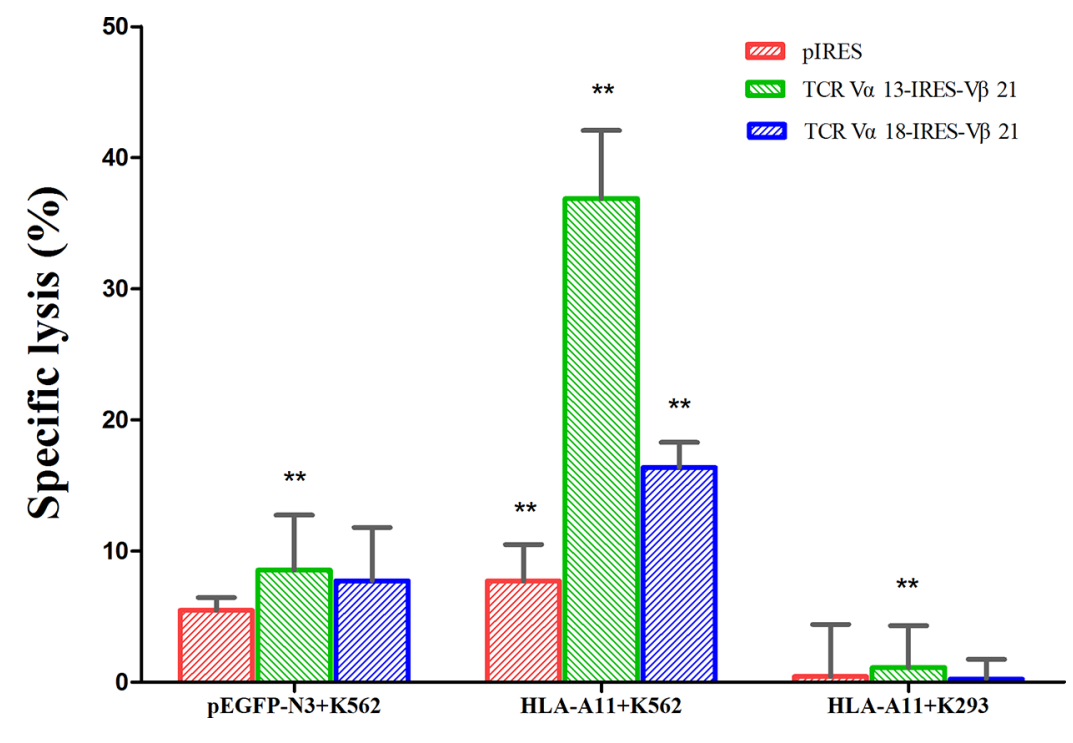

Figure 4: Specific cytotoxicity of TCR gene-transduced $\mathrm{CD3}^{+} \mathrm{T}$ cells against HLA-A11 ${ }^{+} \mathrm{K562}$ cells as determined by calcein-AM release assay. Three days after transduction, $\mathrm{CD}^{+} \mathrm{T}$ cells transduced with $\mathrm{pIRES}$, TCR V $\alpha 13-\mathrm{IRES}-\mathrm{V} \beta 21$, and TCR V $\alpha 18$ IRES-VB21 were co-cultured with pEGFP-N3 ${ }^{+}$K562, HLA-A11 ${ }^{+}$K562 and HLA-A11 ${ }^{+}$K293 cells at a 40:1 ratio for $4 \mathrm{~h}$. Then, the calceinAM level in the supernatant was determined. The spontaneous release of calcein-AM from both target and effector cells was subtracted from the measured values, and the final results are expressed as the percentage of specific cytotoxicity. ${ }^{* *},<0.05$. Error bars, S.D. 
cell line expressing the same HLA-A11 molecules as that in the CML patient as well as the target cells HLA$\mathrm{A} 11^{+} \mathrm{K} 293$ and $\mathrm{pEGFP}-\mathrm{N} 3^{+} \mathrm{K} 562$, which expresses GFP as a negative control. Both the TCR V $\alpha 13 / \mathrm{V} \beta 21$ and TCR V $\alpha 18 / V \beta 21$ gene-modified T cells demonstrated specific cytotoxicity for HLA-A $11^{+} \mathrm{K} 562$ cells. However, the specific cytotoxicity for the TCR V $\alpha 13 / \mathrm{V} \beta 21$ genemodified T cells was superior to that of the TCR V $\alpha 18$ / V $\beta 21$ gene-modified T cells. Both TCR gene-modified $\mathrm{T}$ cells demonstrated non-specific cytotoxicity for HLA$\mathrm{A} 11^{+} \mathrm{K} 293$ and $\mathrm{pEGFP}-\mathrm{N} 3{ }^{+} \mathrm{K} 562$ cells; thus, specific antiCML activity could be verified in this study. In addition, the granular enzyme and perforin gene transcription level and INF- $\gamma$ level of the TCR V $\alpha 13 / \mathrm{V} \beta 21$ gene-modified $\mathrm{T}$ cells, which were co-cultured with HLA-A $11^{+} \mathrm{K} 562$ cells, corresponded to the cytotoxic capacity. These results further demonstrated that TCR V $\alpha 13 / \mathrm{V} \beta 21$ cells have the ability of specifically recognizing CML cells, however, which tumor antigen peptide recognized by TCR V $\alpha 13 /$ V $\beta 21$ remains unclear. Tumor antigens can be broadly categorized into two types - those that are well defined and others that are undefined [33]. In vitro defined tumor antigen could be used to induce normal $\mathrm{T}$ cells to generate antigen specific $\mathrm{T}$ cell clone, then tumor antigen specific TCRs were indentified from these clone. This approach of using defined tumor antigens has been most widely explored in trials of individual antigens [12, 34, 35]. An advantage of using defined antigens for screening of candidate TCRs is easy to monitor specific immune response. However, this approach have been limited due to number of known tumor antigens for use. Alternative method to identify anti-tumor TCRs was to generate anti-tumor $\mathrm{T}$ cell clone expanded from tumor infiltrating lymphocyte (TIL) or induced by intact tumor cells or cell lysate [36]. The disadvantage is that defined antigens recognized by the indentified TCRs were unclear. Similar to the later method, in this study, we directly characterized the clonally expanded TCR clones from CML patients and

A

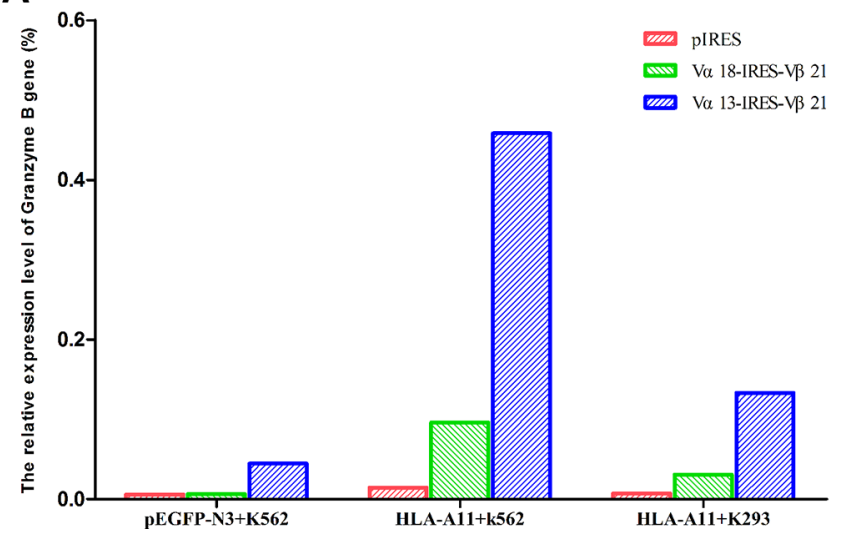

confirmed their cytotoxicity by gene transfer techniques, regardless the defined tumor antigen, this may be the feasible approach for constitution of leukemia-specific $\mathrm{T}$ cell clone. Even we were unable to define the specific antigen of TCR V $\alpha 13 / \mathrm{V} \beta 21$ from oligoclonal T cells of patient with CML, TCR V $\alpha 13 / \mathrm{V} \beta 21$ is still a potential candidate for TCR gene therapy for CML based on their specific cytotoxicity against HLA-A $11^{+} \mathrm{K} 562$ cells.

TCR gene therapy are based on changing $\mathrm{T}$ cell specificity through the expression of $\alpha \beta$ TCRs for mediating the specific antigen recognition process. The procedure include identification of TCR $\alpha$ and $\beta$ chains specific for tumor or leukemia associated antigens and construction of recombinant vectors and transfection of $\mathrm{T}$ cells generates tumor antigen specific $\mathrm{T}$ cells [37]. In the study, the identification of CML associated antigen specific TCR V $\alpha 13 / \mathrm{V} \beta 21$ was the beginning of TCR gene therapy for CML. For clinical applications in the future, the efficient and safety transfection system, TCR misspairing and TCR affinity and avidity must be further solved. Transfer of tumor antigen-specific TCRs to T cells requires a delivery system that yields high-level transfection efficiency and stable transgene expression. Retroviral and lentiviral systems are often using in most clinical studies. These systems are time-consuming and mediate genotoxic side effects. Alternative, more cost-effective and safety, plasmid-based gene transfer systems could offer a way to accelerated screening of a more variety of high affinity tumor antigen specific TCRs [38]. In this study, the selective bicistronic vector pIRES was relative suitable for rapid identifying the antigen specific TCR, which construct simply and fastly and inexpensive, but this plasmid system could not yields stable transgene expression, which limited its clinical application. Future trials, we will select plasmidbased gene transfer systems based on transposable elements such as sleeping beauty (SB) transposon to overcome the problem [39]. TCR mispairing could significantly weaken the functional avidity of the TCR gene modified T cells,

B

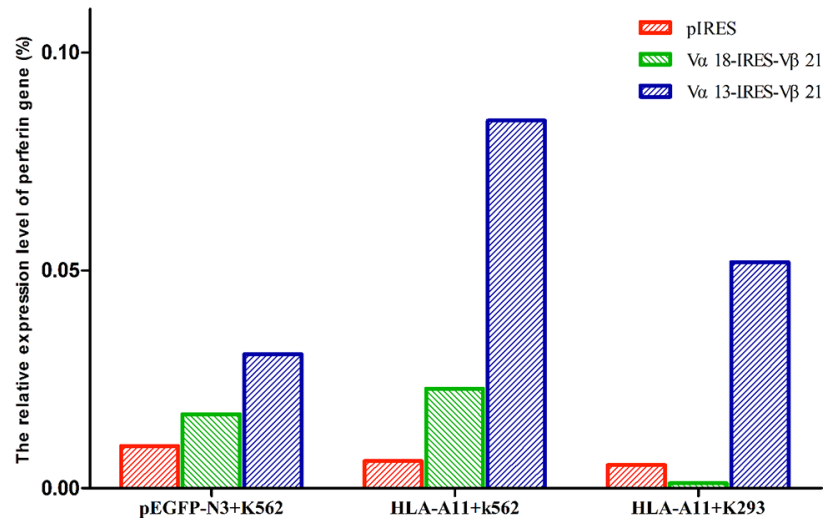

Figure 5: mRNA expression of granzyme B (A) and perforin (B). Three days after transduction, $\mathrm{CD}^{+} \mathrm{T}$ cells transduced with pIRES, TCR V $\alpha 13$-IRES-V $\beta 21$ and V $\alpha 18$-IRES-V $\beta 21$ were co-cultured with pEGFP-N3 ${ }^{+} \mathrm{K} 562$, HLA-A11 ${ }^{+} \mathrm{K} 562$ and HLA-A11 ${ }^{+} \mathrm{K} 293$ cells at a 40:1 ratio for 6 hours. Then, total RNA was extracted and the expression of granzyme B and perforin were detected by RT-PCR. 
because it would reduce the ability of the cells to recognize the desired target peptide and, meanwhile, it can represent a potential risk of autoimmunity [40]. Based on the identified TCR V $\alpha 13 / V \beta 21$, we can employed numerous strategies to minimise the risk of mispairing, including murinization of human TCR-constant regions [41], cysteine modification of TCR chains, modifications of TCR constant chains $[42,43]$, alternation of conventional $\alpha \beta$ TCRs using chimeric antigen receptors $[44,45]$ and introduction of TCR $\alpha \beta$ chains into alternative effector cells [46, 47]. In addition, cytotoxicity assays for different CML cell lines with a large cohort should be performed to confirm the antiCML cytotoxicity.

More recently, advance immunotherapy for leukemia focused on CAR-T cells such as CD19-CAR-T for CD19+ lymphoid leukemia, and bispecific antibody such as a bispecific $\mathrm{T}$ cell engager antibody (BiTE, Blinatumomab), against CD19/CD3 for refractory acute lymphoid leukemia, however, the application is mostly limited in B cell lymphoid leukemia which express CD19, CD20 or CD22 etc [48-50]. Antibodybased therapies, including CAR T cells and bispecific antibody, need recognise surface proteins. However, cell surface proteins as potential tumor targets are few in number, so the application of CAR T cells and bispecific antibody are limited in leukemias which carry specific biomarker in cell surface [51]. So far, none surface specific antigens were found on the cell surface of CML cell, immunotherapy based on TCR-modified CTL may be one of the best approachs. TCRs access both cell surface and intracellular proteins, so theoretically tumor antigen specific TCR gene therapy can be used to treat all tumors.

In summary, to our knowledge, this is the first report identifying CML-associated, antigen-specific TCR V $\alpha 13 / \mathrm{V} \beta 21$. This report provides the preliminary demonstration that TCR V $\alpha 13 / \mathrm{V} \beta 21$ gene-modified T cells have acquired specific anti-CML cytotoxicity. This study provides substantial new data for better understanding TCR-mediated gene therapy in CML.
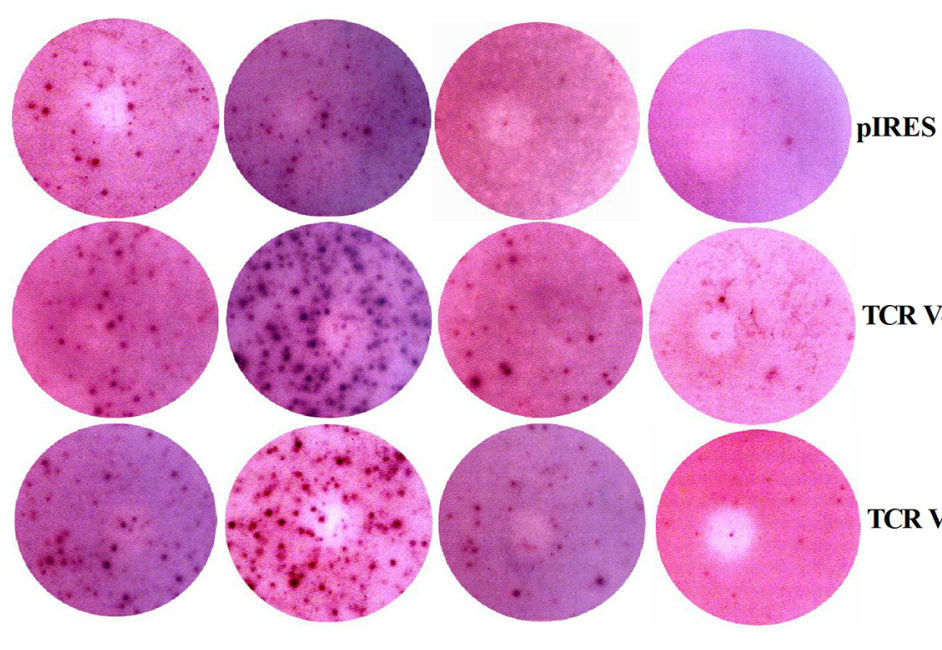

pIRES

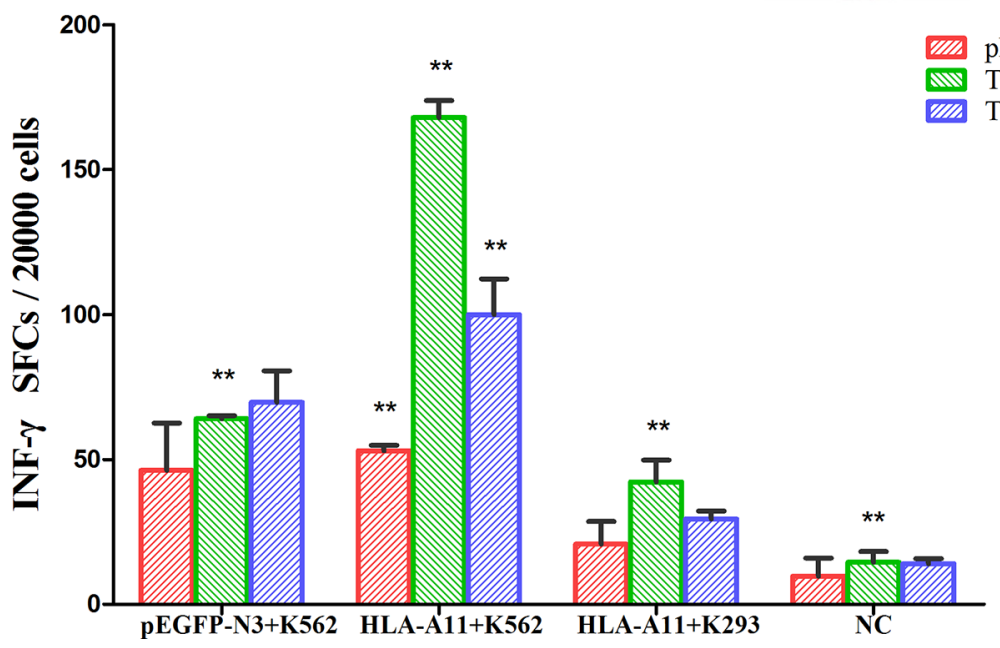

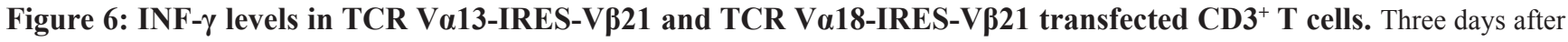
transduction, $\mathrm{CD}^{+}{ }^{+} \mathrm{T}$ cells transduced with pIRES, TCR V $\alpha 13$-IRES-V $\beta 21$ and V $\alpha 18$-IRES-V $\beta 21$ were co-cultured with pEGFP-N3 ${ }^{+} \mathrm{K} 562$, HLA-A $11^{+} \mathrm{K} 562$, and HLA-A $11^{+} \mathrm{K} 293$ cells plus a negative control at a 40:1 ratio for 6 hours. Then, The INF- $\gamma$ was analyzed by ELISPOT array. *The Mann-Whitney test for two independent samples was used to determine differences between various groups. Statistical significance was defined as $P<0.05$. **,$<0.05$. Error bars, S.D. 


\section{MATERIALS AND METHODS}

\section{Samples from a CML patient and healthy donors}

PBMCs were collected from a CML patient (HLA-A*11) after signed informed consent, and PBMCs from three healthy donors served as control. All procedures were conducted according to the guidelines of the Medical Ethics Committees of the Health Bureau of the Guangdong Province of China, and ethical approval was obtained from the Ethics Committee of Medical School of Jinan University.

\section{Cell lines}

K562 cells, Jurkat T cells and HEK-293 cells were cultured in RPMI 1640 supplemented with $10 \%$ heatinactivated fetal bovine serum (FBS), $20 \mathrm{mM}$ HEPES, 0.5 $\mathrm{mM}$ sodium pyruvate, $100 \mathrm{U} / \mathrm{ml}$ penicillin, $100 \mu \mathrm{g} / \mathrm{mL}$ streptomycin, and Glutamax (Invitrogen, Carlsbad, CA).

\section{Construction of TCR V $\alpha 13-I R E S-V \beta 21$ and

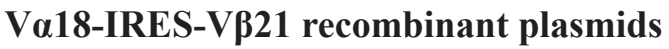

The CML associated-TCR V $\alpha 13, \mathrm{~V} \alpha 18$ and TCR V $\beta 21$ chain genes were isolated from a CML patient [14]. To clone the TCR genes, total RNA was extracted from the PBMCs of the CML patient, and it was reverse transcribed into cDNA. The cDNA was amplified by PCR using forward (VA13-F, VA18-F and VB21-F) and reverse (CA-R, CB-R) primers (Table 1). To construct the TCR V $\alpha 13-I R E S-V \beta 21$ and V $\alpha 18$-IRES-V $\beta 21$ recombinant plasmids, the isolated TCR $\mathrm{V} \alpha 13$ and $\mathrm{V} \alpha 18$ genes were cloned into MCS A of the pIRES vector using the Nhe1 and EcoR1 restriction sites, and the isolated V $\beta 21$ gene was cloned into MCS B of the TCR Va13-IRES and TCR Va18-IRES vectors using Xbal 1 and Sall restriction sites. The recombinant plasmids were then transfected into HEK 293 and Jurkat T cells using lipofectin and Nucleofector ${ }^{\mathrm{TM}}$ technology (Amaxa, Cologne, Germany), and the TCR $\alpha 13, \alpha 18$ and $\beta 21$ proteins were detected using a TCR $\alpha$ and $\beta$ monoclonal antibody (mAb) with laser confocal microscopy (LCM; 510 META DuoScan, Carl Zeiss, Germany) and flow cytometry (FCM) 24 hours after transfection.

\section{Western blot analysis}

HEK 293 cells were harvested 24 hours after transfection, mixed with RIPA lysis buffer $(1 \times$ PBS, $1 \%$ Nonidet P-40, $0.5 \%$ sodium deoxycholate, $0.1 \%$ sodium dodecyl sulfate [SDS], $10 \mathrm{mmol} / \mathrm{L}$ phenylmethylsulfonyl fluoride, $1 \mu \mathrm{g} / \mathrm{mL}$ aprotinin, and $100 \mathrm{mmol} / \mathrm{L}$ sodium orthovanadate), and incubated on ice for $30 \mathrm{~min}$ to isolate total proteins. Proteins $(100 \mu \mathrm{g})$ were separated by $7.5 \%$
SDS-PAGE and transferred to nitrocellulose membranes (Invitrogen, USA) using a damp-dry transfer device (Biorad, USA). After blocking for 1 hours in 5\% defatted milk powder in PBS, the membranes were washed and probed with a mouse anti-human TCR $\beta$ monoclonal antibody and a rabbit anti-human TCR $\alpha$ polyclonal antibody (Santa Cruz, USA). Similar studies were performed with 1:500 mouse-anti-human $\beta$-actin (BOSTER, Wuhan, China). The antibodies were detected using 1:10,000 horseradish peroxidase-conjugated, goat-anti-rabbit IgG and donkeyanti-mouse IgG (Jackson ImmunoResearch, USA). A Western blotting luminol reagent (Tiangen, Beijing, China) was used to visualize bands corresponding to each antibody.

\section{Human $\mathrm{CD3}^{+} \mathrm{T}$ cell isolation and culture}

Peripheral blood mononuclear cells (PBMCs) obtained from three healthy donors (HLA-A*11, DP restricted) were isolated from heparinized venous blood by Ficoll-Paque gradient centrifugation. Cells were collected, washed twice in Hank's balanced salt solution, and resuspended at a final concentration of $2 \times 10^{6}$ cells/ $\mathrm{mL}$ in $\mathrm{T}$ cell medium OpTmizer ${ }^{\mathrm{TM}} \mathrm{SFM}$ (Invitrogen, Grand Island, NY) supplemented with $2 \%$ heat-inactivated fetal calf serum (FCS; HyClone, Logan, UT), $100 \mathrm{U} / \mathrm{mL}$ penicillin, $100 \mu \mathrm{g} / \mathrm{mL}$ streptomycin, $2 \mathrm{mM}$ L-glutamine, and $50 \mu \mathrm{M} 2$-mercaptoethanol. $\mathrm{CD}^{+} \mathrm{T}$ cells were purified from freshly isolated PBMCs using $\mathrm{CD}^{+}$microbeads (Miltenyi Biotec, Bergisch Gladbach, Germany) according to the manufacturer's protocol. The purity of the collected $\mathrm{CD}^{+} \mathrm{T}$ cells was assessed by flow cytometry. Greater than $95 \%$ of the $\mathrm{CD}^{+} \mathrm{T}$ cells were collected using this technique. Initial stimulation was performed at a concentration of $2 \times 10^{6}$ cells per well in $1 \mathrm{~mL}$ $\mathrm{T}$ cell medium OpTmizer ${ }^{\mathrm{TM}}$ SFM (containing $200 \mathrm{IU} / \mathrm{mL}$ IL-2, $1 \mu \mathrm{g} / \mathrm{mL}$ OKT3 and $2 \mu \mathrm{g} / \mathrm{mL}$ CD28 monoclonal antibody) for $24 \mathrm{~h}$ in non-tissue culture 12-well plates. Cells were washed once with medium on the following day and then added to fresh complete RPMI 1640 medium supplemented with $200 \mathrm{IU} / \mathrm{ml} \mathrm{IL}-2$.

\section{Artificial killing of target cell lines}

To generate artificial killing of target cells, the K562 cell line was modified to express human HLA-A*11 with an HLA-A*11-2A-eGFP vector using transduction. After transduction, K562 cells were selected by drug resistance (G418) and the limited dilution method to obtain an HLA-A* $11^{+}$K562 cell clone [16]. This clone was then expanded, and the expression of the transgenic molecules was monitored by fluorescence-activated cell sorting (FACS) over time. In addition, the pEGFP-N3 ${ }^{+} \mathrm{K} 562$ and HLA-A11 ${ }^{+} \mathrm{K} 293$ cell clones were constructed as negative control cell lines. 
Table 1: The sequence of primers for PCR

\begin{tabular}{|c|c|c|}
\hline Primers & Sequence & Function \\
\hline VA13-F & $\begin{array}{l}\text { 5'-TCGGCTAGCGGAGCAAGAAGGC } \\
\text { AAAGCATC-3' }\end{array}$ & $\begin{array}{l}\text { Sense primer for TCR } \alpha 13 \text { genes in the } 5^{\prime} \text { position of IRES } \\
\text { containing Nhe I restriction enzyme sites }\end{array}$ \\
\hline VA18-F & $\begin{array}{l}\text { 5'-TCGGCTAGCTGAGCAGGAAACA } \\
\text { TGGAGAAGAAT-3' }\end{array}$ & $\begin{array}{l}\text { Sense primer for TCR } \alpha 18 \text { genes in the } 5^{\prime} \text { position of IRES } \\
\text { containing Nhe I restriction enzyme sites }\end{array}$ \\
\hline CA-R & $\begin{array}{l}\text { 5'-ATTGAATTCGCGAGGGAGCACA } \\
\text { GGCTGTCTTAC-3' }\end{array}$ & $\begin{array}{l}\text { Antisense primer for TCR } \alpha 13 \text { and } \alpha 18 \text { genes in the } 3^{\prime} \text { position } \\
\text { of IRES containing } \boldsymbol{E c o R} \boldsymbol{I} \text { restriction enzyme sites }\end{array}$ \\
\hline VB21-F & $\begin{array}{l}\text { 5'-TAAGCTAGCCTCCCATCCTTCCC } \\
\text { TGACCCT-3' }\end{array}$ & $\begin{array}{l}\text { Sense primer for TCR } \beta 21 \text { genes in the } 5^{\prime} \text { position of IRES } \\
\text { containing Nhe I restriction enzyme sites }\end{array}$ \\
\hline CB-R & $\begin{array}{l}\text { 5'-GCCGAATTCTCAGCCTCTGGAAT } \\
\text { CCTTTCTCTTGAC-3' }\end{array}$ & $\begin{array}{l}\text { Antisense primer for TCR } \beta 21 \text { genes in the } 3^{\prime} \text { position of IRES } \\
\text { containing } \boldsymbol{E} \text { coR } \boldsymbol{I} \text { restriction enzyme sites }\end{array}$ \\
\hline grmb-f & 5'- AGATGCAACCAATCCTGCTT-3' & Sense primer for granzyme B \\
\hline grmb-r & 5'-CATGTCCCCCGATGATCT-3' & Antisense primer for granzyme B \\
\hline perf-f & 5'- CCGCTTCTCTATACGGGATTC-3' & Sense primer for perforin \\
\hline perf-r & 5'- GCAGCAGCAGGAGAAGGAT-3' & Antisense primer for perforin \\
\hline gapdh-f & 5'-AGCCACATCGCTCAGACAC-3' & Sense primer for GAPDH \\
\hline gapdh-r & 5'-GCCCAATACGACCAAATCC-3' & Antisense primer for GAPDH \\
\hline
\end{tabular}

\section{Transduction of TCR genes in $T$ cells}

Human $\mathrm{CD}^{+} \mathrm{T}$ cells were transfected using Nucleofector ${ }^{\mathrm{TM}}$ technology (Amaxa, Cologne, Germany). Briefly, cells $\left(1 \times 10^{7}\right)$ were resuspended in $0.1 \mathrm{~mL}$ supplemented Nucleofector solution at room temperature from the human $\mathrm{T}$ cell Nucleofector ${ }^{\mathrm{TM}} \mathrm{kit}$. Each plasmid (5 $\mu \mathrm{g}$; including the TCR Vo13-IRESV $\beta 21$ and TCR V $\alpha 18$-IRES-V $\beta 21$ recombinant plasmids and the negative control TCR empty vector) was mixed with $0.1 \mathrm{~mL}$ cell suspension, transferred to a $2.0 \mathrm{~mm}$ electroporation cuvette, and nucleofected using an Amaxa Nucleofector II apparatus according to the manufacturer's guidelines. Storage of the cell suspension in human T cell Nucleofector solution for longer than $20 \mathrm{~min}$ was avoided as this reduces cell viability and gene transfer efficiency. The cells were transfected using the U-014 program. The transfected $\mathrm{T}$ cells were immediately transferred to prewarmed T cell medium OpTmizer ${ }^{\mathrm{TM}} \mathrm{SFM}$ and cultured in 12 -well plates in a humidified incubator at $37^{\circ} \mathrm{C}$ and $5 \%$ $\mathrm{CO}_{2}$. The culture medium was changed at $4-6$ and 18 hours after transfection to T cell medium containing $200 \mathrm{IU} / \mathrm{mL}$ IL-2 and $2 \%$ FCS. The monoclonal antibodies $1 \mu \mathrm{g} / \mathrm{mL}$ OKT3 and $2 \mu \mathrm{g} / \mathrm{mL}$ CD28 were later added, and the cells were cultured for 48 hours. T cells were stained with CD3$\mathrm{PE}$ and Vß21.3-PE (Beckman Coulter, California, USA) to monitor TCR expression. Flow cytometry was performed using a FACS Canto flow cytometer (BD Biosciences).

\section{Calcein-acetyoxymethyl cytotoxicity assay}

Calcein-AM was purchased from Molecular Probes (Eugene, OR) as a $1 \mathrm{mg} / \mathrm{ml}$ solution in dry dimethyl sulfoxide. Target cells (pEGFP-N3 ${ }^{+}$K562 cell, HLA-A11 ${ }^{+}$ $\mathrm{K} 562$ cell, and HLA-A $11^{+} \mathrm{K} 293$ cell) were resuspended in complete medium at a final concentration of $10^{3} / \mu \mathrm{L}$ and incubated with $15 \mu \mathrm{M}$ calcein-AM for $30 \mathrm{~min}$ at $37^{\circ} \mathrm{C}$ with occasional shaking. After two washes in complete medium, cells were adjusted to $10^{2} / \mu \mathrm{L}$ in $\mathrm{U}$ bottom 96 well microtiter plates (Nunc, USA) with an E:T ratio of 40:1 in triplicate with at least six replicate wells for spontaneous (only target cells in complete medium) and maximum release (target cells in the medium alone plus $2 \%$ Triton X-100). The numbers of TCR gene-transferred $\mathrm{T}$ cells (effector cells) and labeled target tumor cells were seeded as follows: each well contained $2 \times 10^{5}$ lymphocytes in $100 \mu \mathrm{L}$ complete medium and $5 \times 10^{3}$ target cells $/ 50 \mu \mathrm{L}$ of complete medium. After incubation at $37^{\circ} \mathrm{C}$ in $5 \% \mathrm{CO}_{2}$ for $4 \mathrm{~h}, 75 \mu \mathrm{L}$ of each supernatant was harvested and transferred into new plates. Samples were measured using an ELX 800 absorbance reader (BioTEK, USA) (excitation filter: $485 \pm 9 \mathrm{~nm}$; band-pass filter: $530 \pm 9 \mathrm{~nm}$ ). Data were expressed as arbitrary fluorescent units (AFU). Specific lysis was calculated according to the following formula: [(experimental release-target spontaneous release-effector spontaneous release)/(target maximum release-target spontaneous release)] $\times 100 \%$.

\section{Quantitative real-time reverse transcription (RT)-PCR analysis}

After the calcein-AM cytotoxicity assay, total RNA from mixed cells was extracted using the RNeasy Mini kit (Qiagen, Valencia, CA) following the manufacturer's instructions. Granzyme B and perforin mRNA were measured by real-time quantitative reverse transcription polymerase chain reaction (qRT-PCR) analysis using $\mathrm{SYBR}^{\circledR}$ Green I with the Real Master Mix kit (Tiangen, Beijing, China). Reactions were run in triplicate and repeated in three independent experiments using the CFX real-time PCR system (Bio-Rad, USA) with cDNA template in a $25 \mu \mathrm{L}$ reaction under the following conditions: $95^{\circ} \mathrm{C}$ for $2 \mathrm{~min}$ followed by 45 cycles of $95^{\circ} \mathrm{C}$ for $15 \mathrm{~s}, 65^{\circ} \mathrm{C}$ for $15 \mathrm{~s}$ and $72^{\circ} \mathrm{C}$ for $40 \mathrm{~s}$. The primers 
used for real-time PCR are listed in Table 1 as described by Nagai K et al. [52].

\section{ELIspot assay}

The IFN- $\gamma$ ELIspot assay was performed as described by Paret $\mathrm{C}$ et al. [35]. Briefly, the TCR genetransferred $\mathrm{T}$ cells were plated in triplicate and serially diluted at $2 \times 10^{4}$ cells/well, and $8 \times 10^{4}$ target cells that were treated with Mitomycin-C were added. In all experiments, TCR gene-transferred $\mathrm{T}$ cells were also incubated with free medium as a negative control. Plates were incubated in $5 \% \mathrm{CO}_{2}$ at $37^{\circ} \mathrm{C}$ for 24 hours. The medium and cells were removed and $200 \mu \mathrm{L}$ deionized water was added and incubated on ice for $10 \mathrm{~min}$. After washing ten times with PBS containing $0.05 \%$ Tween-20, $100 \mu \mathrm{L}$ biotinylated anti-IFN- $\gamma$ antibody was added to each well, and plates were incubated at $37^{\circ} \mathrm{C}$ for 1 hour. The plates were washed again and incubated with HRPlabeled streptavidin at $37^{\circ} \mathrm{C}$ for $1 \mathrm{~h}$. After washing the plates again, $100 \mu \mathrm{l}$ of AEC solution was added to each well, and the plates were incubated at room temperature for $30 \mathrm{~min}$. The color reaction was stopped by washing the plates with deionized water. The spots were counted with a body vision microscope; each spot represented an IFN$\gamma$-secreting cell, and the average of the three wells was calculated as the detection value. The number of specific CTLs was determined as spots per 20,000 effector cells.

\section{Statistical analysis}

The Mann-Whitney test for two independent samples was used to determine differences between groups using SPSS 11.5 statistical software. Differences with a $P<0.05$ were considered statistically significant.

\section{ACKNOWLEDGMENTS AND FUNDING}

This study was supported by grants from the National Natural Science Foundation of China (Nos. 81270604 and 81400109), the China Postdoctoral Science Foundation (No. 2013M540685), the Guangdong Natural Science Foundation (Nos. S2013040016151 and S2013020012863), the Guangdong Provincial Basic Research Program (No. 2015B020227003), the Foundation for High-level Talents in Higher Education of Guangdong, China (No.[2013] 24654), the Guangdong Provincial Applied Science and Technology Research \& Development Program (Grant No.: 2016B020237006), the Guangzhou Science and Technology Project foundation (201510010211), the Medical Science Foundation of Guangdong Province (No. B2013213), and the Fundamental Research Funds for the Central Universities (Nos. 21613313 and 21616108).

\section{CONFLICTS OF INTEREST}

The authors declare that they have no competing interests.

\section{REFERENCES}

1. Chopra R, Pu QQ, Elefanty AG. Biology of BCR-ABL. Blood Rev. 1999; 13:211-229.

2. Druker BJ, Sawyers CL, Kantarjian H, Resta DJ, Reese SF, Ford JM, Capdeville R, Talpaz M. Activity of a specific inhibitor of the BCR-ABL tyrosine kinase in the blast crisis of chronic myeloid leukemia and acute lymphoblastic leukemia with the Philadelphia chromosome. N Engl J Med. 2001; 344:1038-1042.

3. Marin D, Milojkovic D, Olavarria E, Khorashad JS, de Lavallade H, Reid AG, Foroni L, Rezvani K, Bua M, Dazzi F, Pavlu J, Klammer M, Kaeda JS, et al. European LeukemiaNet criteria for failure or suboptimal response reliably identify patients with CML in early chronic phase treated with imatinib whose eventual outcome is poor. Blood. 2008; 112:4437-4444.

4. Jangamreddy JR, Panigrahi S, Lotfi K, Yadav M, Maddika S, Tripathi AK, Sanyal S, Los MJ. Mapping of apoptininteraction with BCR-ABL1, and development of apoptinbased targeted therapy. Oncotarget. 2014; 5:7198-7211. doi: 10.18632/oncotarget.2278.

5. Hehlmann R, Hochhaus A, Baccarani M. Chronic myeloid leukaemia. Lancet. 2007; 370:342-350.

6. Baron F, Labopin M, Ruggeri A, Mohty M, Sanz G, Milpied N, Bacigalupo A, Rambaldi A, Bonifazi F, Bosi A, Sierra J, Yakoub-Agha I, Santasusana JM, et al. Unrelated cord blood transplantation for adult patients with acute myeloid leukemia: higher incidence of acute graft-versushost disease and lower survival in male patients transplanted with female unrelated cord blood - a report from Eurocord, the Acute Leukemia Working Party, and the Cord Blood Committee of the Cellular Therapy and Immunobiology Working Party of the European Group for Blood and Marrow Transplantation. J Hematol Oncol. 2015; 8:107.

7. Pinilla-Ibarz J, Shah B, Dubovsky JA. The biological basis for immunotherapy in patients with chronic myelogenous leukemia. Cancer control. 2009; 16:141-152.

8. Nicholson E, Ghorashian S, Stauss H. Improving TCR Gene Therapy for Treatment of Haematological Malignancies. Adv Hematol. 2012; 2012:404081.

9. Engels B, Uckert W. Redirecting $T$ lymphocyte specificity by $\mathrm{T}$ cell receptor gene transfer - a new era for immunotherapy. Mol Aspects Med. 2007; 28:115-142.

10. Keilholz U, Letsch A, Busse A, Asemissen AM, Bauer S, Blau IW, Hofmann WK, Uharek L, Thiel E, Scheibenbogen C. A clinical and immunologic phase 2 trial of Wilms tumor gene product 1 (WT1) peptide vaccination in patients with AML and MDS. Blood. 2009; 113:6541-6548. 
11. Yang D, Shao Q, Sun H, Mu X, Gao Y, Jiang R, Hou J, Yao K, Chen Y, Sun B. Evaluation of Epstein-Barr virus latent membrane protein 2 specific T-cell receptors driven by T-cell specific promoters using lentiviral vector. Clin Dev Immunol. 2011; 2011:716926.

12. Hu Z, Xia J, Fan W, Wargo J, Yang YG. Human melanoma immunotherapy using tumor antigen-specific $\mathrm{T}$ cells generated in humanized mice. Oncotarget. 2016; 7:6448-6459. doi: 10.18632/oncotarget.7044.

13. Asai H, Fujiwara H, Kitazawa S, Kobayashi N, Ochi T, Miyazaki Y, Ochi F, Akatsuka Y, Okamoto S, Mineno J, Kuzushima K, Ikeda H, Shiku H, et al. Adoptive transfer of genetically engineered WT1-specific cytotoxic T lymphocytes does not induce renal injury. J Hematol Oncol. 2014; 7:3.

14. Zha X, Chen S, Yang L, Li B, Chen Y, Yan X, Li Y. Characterization of the CDR3 structure of the Vbeta21 $\mathrm{T}$ cell clone in patients with $\mathrm{P} 210(\mathrm{BCR}-\mathrm{ABL})$-positive chronic myeloid leukemia and B-cell acute lymphoblastic leukemia. Hum Immunol. 2011; 72:798-804.

15. Quintarelli C, Dotti G, De Angelis B, Hoyos V, Mims M, Luciano L, Heslop HE, Rooney CM, Pane F, Savoldo B. Cytotoxic $\mathrm{T}$ lymphocytes directed to the preferentially expressed antigen of melanoma (PRAME) target chronic myeloid leukemia. Blood. 2008; 112:1876-1885.

16. Zha XF, Zhou YB, Yang LJ, Chen SH, Li B, Yan XJ, Li YQ. [Establishment of stable subline of K562 cells expressing human leucocyte antigen a1101]. Zhongguo Shi Yan Xue Ye Xue Za Zhi. 2011; 19:1112-1116.

17. Fujiwara H. Adoptive T-cell therapy for hematological malignancies using T cells gene-modified to express tumor antigen-specific receptors. Int J Hematol. 2014; 99:123-131.

18. Ochi T, Fujiwara H, Okamoto S, An J, Nagai K, Shirakata T, Mineno J, Kuzushima K, Shiku H, Yasukawa M. Novel adoptive T-cell immunotherapy using a WT1-specific TCR vector encoding silencers for endogenous TCRs shows marked antileukemia reactivity and safety. Blood. 2011; 118:1495-1503.

19. Yin Q, Zha X, Yang L, Chen S, Zhou Y, Wu X, Li Y. Generation of diffuse large B cell lymphoma-associated antigen-specific Valpha6/Vbeta13+T cells by TCR gene transfer. J Hematol Oncol. 2011; 4:2.

20. Clark RE, Christmas SE. BCR-ABL fusion peptides and cytotoxic $\mathrm{T}$ cells in chronic myeloid leukaemia. Leuk Lymphoma. 2001; 42:871-880.

21. Wagner WM, Ouyang Q, Pawelec G. The abl/bcr gene product as a novel leukemia-specific antigen: peptides spanning the fusion region of abl/bcr can be recognized by both $\mathrm{CD} 4+$ and CD8+ T lymphocytes. Cancer Immunol Immunother. 2003; 52:89-96.

22. Yotnda P, Firat H, Garcia-Pons F, Garcia Z, Gourru G, Vernant JP, Lemonnier FA, Leblond V, LangladeDemoyen $\mathrm{P}$. Cytotoxic $\mathrm{T}$ cell response against the chimeric p210 BCR-ABL protein in patients with chronic myelogenous leukemia. J Clin Invest. 1998; 101:2290-2296.
23. Rusakiewicz S, Madrigal A, Travers P, Dodi AI. BCR/ ABL-specific CD8+ T cells can be detected from CML patients, but are only expanded from healthy donors. Cancer Immunol Immunother. 2009; 58:1449-1457.

24. Nieda M, Nicol A, Kikuchi A, Kashiwase K, Taylor K, Suzuki K, Tadokoro K, Juji T. Dendritic cells stimulate the expansion of bcr-abl specific CD8+ T cells with cytotoxic activity against leukemic cells from patients with chronic myeloid leukemia. Blood. 1998; 91:977-983.

25. Bosch GJ, Joosten AM, Kessler JH, Melief CJ, Leeksma OC. Recognition of BCR-ABL positive leukemic blasts by human CD4+ T cells elicited by primary in vitro immunization with a BCR-ABL breakpoint peptide. Blood. 1996; 88:3522-3527.

26. Yasukawa M, Ohminami H, Kaneko S, Yakushijin Y, Nishimura Y, Inokuchi K, Miyakuni T, Nakao S, Kishi K, Kubonishi I, Dan K, Fujita S. CD4(+) cytotoxic T-cell clones specific for bcr-abl b3a2 fusion peptide augment colony formation by chronic myelogenous leukemia cells in a b3a2-specific and HLA-DR-restricted manner. Blood. 1998; 92:3355-3361.

27. Sensi M, Parmiani G. Analysis of TCR usage in human tumors: a new tool for assessing tumor-specific immune responses. Immunol Today. 1995; 16:588-595.

28. Long SA, Khalili J, Ashe J, Berenson R, Ferrand C, Bonyhadi M. Standardized analysis for the quantification of Vbeta CDR3 T-cell receptor diversity. J Immunol Methods. 2006; 317:100-113.

29. Okajima M, Wada T, Nishida M, Yokoyama T, Nakayama Y, Hashida Y, Shibata F, Tone Y, Ishizaki A, Shimizu M, Saito T, Ohta K, Toma T, et al. Analysis of T cell receptor Vbeta diversity in peripheral CD4 and CD8 T lymphocytes in patients with autoimmune thyroid diseases. Clin Exp Immunol. 2009; 155:166-172.

30. Han H, Yuan F, Sun Y, Liu J, Liu S, Luo Y, Liang F, Liu N, Long J, Zhao X, Kong F, Xi Y. Three-dimensional structure discrepancy between HLA alleles for effective prediction of aGVHD severity and optimal selection of recipient-donor pairs: a proof-of-concept study. Oncotarget. 2015; 6:4033740359. doi: 10.18632/oncotarget.5378.

31. Li Y, Yang L, Chen S, Zhang Y, Wu X. The TCR Vbeta repertoire usage of T-cells from cord blood induced by chronic myelogenous leukemia associated antigen. Hematology. 2005; 10:387-392.

32. Xu L, Lu Y, Lai J, Yu W, Zhang Y, Jin Z, Xu Y, Chen J, Zha X, Chen S, Yang L, Li Y. Characteristics of the TCR Vbeta repertoire in imatinib-resistant chronic myeloid leukemia patients with ABL mutations. Sci China Life Sci. 2015; 58:1276-1281.

33. Srinivasan R, Wolchok JD. Tumor antigens for cancer immunotherapy: therapeutic potential of xenogeneic DNA vaccines. J Transl Med. 2004; 2:12.

34. Leisegang M, Kammertoens T, Uckert W, Blankenstein T. Targeting human melanoma neoantigens by $\mathrm{T}$ cell receptor gene therapy. J Clin Invest. 2016; 126:854-858. 
35. Paret C, Simon P, Vormbrock K, Bender C, Kolsch A, Breitkreuz A, Yildiz O, Omokoko T, Hubich-Rau S, Hartmann C, Hacker S, Wagner M, Roldan DB, et al. CXorf61 is a target for $\mathrm{T}$ cell based immunotherapy of triplenegative breast cancer. Oncotarget. 2015; 6:25356-25367. doi: 10.18632/oncotarget.4516.

36. Duong CP, Yong CS, Kershaw MH, Slaney CY, Darcy PK. Cancer immunotherapy utilizing gene-modified T cells: From the bench to the clinic. Mol Immunol. 2015; 67:46-57.

37. Sharpe M, Mount N. Genetically modified T cells in cancer therapy: opportunities and challenges. Dis Model Mech. $2015 ; 8: 337-350$.

38. Field AC, Vink C, Gabriel R, Al-Subki R, Schmidt M, Goulden N, Stauss H, Thrasher A, Morris E, Qasim W. Comparison of lentiviral and sleeping beauty mediated alphabeta $\mathrm{T}$ cell receptor gene transfer. PLoS One. 2013; 8:e68201.

39. Deniger DC, Pasetto A, Tran E, Parkhurst MR, Cohen CJ, Robbins PF, Cooper LJ, Rosenberg SA. Stable, Nonviral Expression of Mutated Tumor Neoantigen-specific T-cell Receptors Using the Sleeping Beauty Transposon/ Transposase System. Mol Ther. 2016; 24:1078-1089.

40. Morris EC, Stauss HJ. Optimizing T-cell receptor gene therapy for hematologic malignancies. Blood. 2016; 127:3305-3311.

41. Bialer G, Horovitz-Fried M, Ya'acobi S, Morgan RA, Cohen CJ. Selected murine residues endow human TCR with enhanced tumor recognition. J Immunol. 2010; 184:6232-6241.

42. Sommermeyer D, Uckert W. Minimal amino acid exchange in human TCR constant regions fosters improved function of TCR gene-modified T cells. J Immunol. 2010; 184:6223-6231.

43. Sebestyen Z, Schooten E, Sals T, Zaldivar I, San Jose E, Alarcon B, Bobisse S, Rosato A, Szollosi J, Gratama JW, Willemsen RA, Debets R. Human TCR that incorporate CD3zeta induce highly preferred pairing between TCRalpha and beta chains following gene transfer. J Immunol. 2008; 180:7736-7746.

44. Magnani CF, Turazzi N, Benedicenti F, Calabria A, Tenderini E, Tettamanti S, Giordano Attianese GM, Cooper LJ, Aiuti A, Montini E, Biondi A, Biagi E.
Immunotherapy of acute leukemia by chimeric antigen receptor-modified lymphocytes using an improved Sleeping Beauty transposon platform. Oncotarget. 2016' 7:5158151597. doi: 10.18632/oncotarget.9955.

45. Knies D, Klobuch S, Xue SA, Birtel M, Echchannaoui H, Yildiz O, Omokoko T, Guillaume P, Romero P, Stauss H, Sahin U, Herr W, Theobald M, et al. An optimized single chain TCR scaffold relying on the assembly with the native CD3-complex prevents residual mispairing with endogenous TCRs in human T-cells. Oncotarget. 2016; 7:21199-21221. doi: 10.18632/oncotarget.8385.

46. Saito H, Okita K, Chang AE, Ito F. Adoptive Transfer of CD8+ T Cells Generated from Induced Pluripotent Stem Cells Triggers Regressions of Large Tumors Along with Immunological Memory. Cancer Res. 2016; 76:3473-3483.

47. Thomas S, Stauss HJ, Morris EC. Molecular immunology lessons from therapeutic T-cell receptor gene transfer. Immunology. 2010; 129:170-177.

48. Wu J, Fu J, Zhang M, Liu D. Blinatumomab: a bispecific $\mathrm{T}$ cell engager (BiTE) antibody against CD19/CD3 for refractory acute lymphoid leukemia. J Hematol Oncol. 2015; 8:104.

49. An N, Tao Z, Li S, Xing H, Tang K, Tian Z, Rao Q, Wang M, Wang J. Construction of a new anti-CD19 chimeric antigen receptor and the anti-leukemia function study of the transduced T cells. Oncotarget. 2016; 7:10638-10649. doi: 10.18632/oncotarget.8385.

50. Jacoby E, Nguyen SM, Fountaine TJ, Welp K, Gryder B, Qin H, Yang Y, Chien CD, Seif AE, Lei H, Song YK, Khan J, Lee DW, et al. CD19 CAR immune pressure induces B-precursor acute lymphoblastic leukaemia lineage switch exposing inherent leukaemic plasticity. Nat Commun. 2016; 7:12320.

51. Sadelain M, Brentjens R, Riviere I. The basic principles of chimeric antigen receptor design. Cancer Discov. 2013; 3:388-398.

52. Nagai K, Takahashi Y, Mikami I, Fukusima T, Oike H, Kobori M. The hydroxyflavone, fisetin, suppresses mast cell activation induced by interaction with activated $\mathrm{T}$ cell membranes. Br J Pharmacol. 2009; 158:907-919. 